\title{
Changes in Export Shares and Competitive Strength in Pakistan
}

\author{
ZAFAR MAHMOOD ${ }^{*}$
}

The constant-market-Share technique provides useful information for analyzing export performance by allowing realised export growth to be separated into commodity composition, market diversification, world trade and export promotion effects. Furthermore, the analysis of export promotion effect provides information about the control variables which can be instrumental in formulating future export policies. The study provides information concerning the extent to which Pakistan is exporting to markets with relatively unfavourable grow th rates.

Most of the developing countries like Pakistan face serious balance-of-payments problems. These problems arise mainly from the failure of these countries' exports to grow fast enough to meet their growing import requirements. During the Seventies, Pakistan's exports, at the constant prices of 1970 , increased at a rate of one percent per annum only. The performance was more disappointing during the 1972-1976 period, when exports declined from Rs. 3068 million in 1972 to Rs. 2507 million in 1976. This should be a cause for concern to the policy-makers and to the academics alike. It is, therefore, essential that the main factors responsible for the decline in exports be studied closely, to enable the government to formulate adequate export-promotion policies.

The importance of different factors in the growth of exports is best ascertained by conducting the Constant-Market-Share (CMS) analysis. This approach essentially decomposes growth of actual export during a specified period into four parts, viz. the 'commodity composition effect', the 'market diversification effect' (referred to in the literature as 'market distribution effect'), 'the world trade effect', and a 'residual' (redesignated in this paper as 'export promotion effect' to reflect the

*The author is Research Economist at the Pakistan Institute of Development Economics. $\mathrm{He}$ is grateful to Prof. Sukesh K. Ghosh, who supervised this study in the initial stages. He is deeply indebted to Professor Syed Nawab Haider Naqvi, A. R. Kemal and anonymous referees for their valuable comments on an earlier draft of the paper.

${ }^{1}$ Since a major proportion of the 'residual' is explained in terms of the discretionary government policies to promote exports, the 'residual' has been labelled as the 'export promotion effect' in this study. This still leaves out the 'random' part of the residual, which remains unexplained. 
effects of other variables such as changes in the competitiveness, domestic supply situation, etc.). The main advantage of the CMS analysis is that it makes it possible to isolate the effects of changes in 'commodity composition', 'market diversification' and 'world trade' from other factors, some of which can be controlled by appropriate government actions; further, this study compares the actual growth of exports with the expected level of exports on the assumption that any given country's share in total world exports remains constant over time. The CMS analysis highlights the importance, for the growth of a country's exports, of such factors as the growth in world trade, the nature of commodities exported and the growth of demand for these products in the importing countries. Once these three factors are accounted for, it is possible to assess the importance of discretionary factors, reflected in the 'export promotion effect', in the growth of domestic exports.

The CMS approach was first used by Tyszinsky [20] to study changes in the market shares of the exports of West-European countries for the 1899-1950 period. However, his analysis was limited in that he decomposed the growth of exports into only two components, viz. changes in world trade and the 'residual', which, as mentioned earlier, is referred to as 'export promotion effect' in this study. As Richardson [16] pointed out, a comprehensive analysis of the growth of exports should involve the estimation of the 'commodity composition' and 'market diversification' effects as well. Accordingly, most of the CMS studies done recently decompose export growth into four parts - viz. the 'commodity composition effect', the 'market diversification effect', the 'world trade effect' and the 'export promotion effect'. However, in all the studies available so far the 'export promotion effect' has been left unexplained. In a different context, Balassa [1] and Fleming and Tsiang [2] have analysed the relationship of changes in market shares with exports prices and alternatively with domestic costs of production in manufacturing sector. Little, Scitovsky and Scott [10] and Hussain [6] have used the CMS analysis to evalaute Pakistan's export performance of manufactured goods. The former study covers two time periods - 1950-1953 to 1960-1963 and 1960-1963 to 1964-1965 - while the latter covers the period from 1960-1961 to 1967-1968. However, in both the studies, the impact of market diversification on the growth of exports has been ignored. The present study decomposes the growth of exports into the aforementioned four components and analyses the factors giving rise to the 'export promotion effect'. The 'export promotion effect' given prominence to in the present study highlights the crucial importance of domestic policies in promoting export expansion. Such an analysis, by focusing on the adequacy or inadequacy of the domestic efforts, should provide useful guidelines to the policy-maker.

The plan of the paper is as follows: Section I deals with methodological issues and data problems, while Section II presents an empirical analysis of market shares and the competitive strength of Pakistan's exports during the 1972-1976 period. In Section III are set out the policy implications of the study. The main conclusions of the study are listed in Section IV.

\section{METHODOLOGICAL ISSUES AND DATA PROBLEMS}

Following Richardson [16], the growth of Pakistan's exports has been decomposed in this paper into four components, viz. 'world trade effect', 'commodity composition effect', 'market diversification effect' and 'export promotion effect'. The disaggregation of the growth of exports into its four components is shown by

$\xi=\left(V^{\prime}-V\right) \equiv g V+\sum_{i}\left(g_{i}-g\right) V_{i}+\sum_{i j} \sum_{j}\left(g_{i j}-g_{i}\right) V_{i j}+\sum_{i j} \sum\left(V_{i j}^{\prime}-V_{i j}-g_{i j} \cdot V_{i j}\right) \cdot(i)$

where

$\xi \quad=$ Actual changes in the value of exports during the specific period;

$\mathrm{V}=$ Real value of the total domestic exports in the base year;

$\mathrm{V}^{\prime}=$ Real value of the total domestic exports in the final year;

$\mathrm{V}_{\mathrm{i}}=$ Real value of the domestic exports of the ith commodity to all the countries in the base year;

$\mathrm{V}_{\mathrm{ij}}=$ Real value of the domestic exports of the ith commodity to the jth country in the base year;

$\mathrm{V}_{\mathrm{ij}}^{\prime}=$ Real value of the domestic exports of the ith commodity to the jth country in the final year;

$\mathrm{g}=$ Percentage change in total world's exports from the base to the final year;

$\mathrm{g}_{\mathrm{i}}=$ Percentage change in world's exports of the ith commodity from the base to the final year; and

$\mathrm{g}_{\mathrm{ij}}=$ Percentage change in world's exports of the ith commodity to the jth country from base to the final year.

The left-hand side of identity (i) shows the changes in the value of Pakistan's exports during the 1972-1976 period. The first element of the right-hand side of identity (i) shows the expected growth of Pakistan's exports corresponding to the growth rate of total world trade in the base year; while the second element measures the effect of the differential in the growth rate of world trade in the ith commodity and that of the world trade as a whole - known as 'commodity composition effect'. The sign of this expression indicates whether the commodity composition of a country's exports is favourable or unfavourable for the growth of its exports. The third element estimates the effect of the differential between the growth rates of the exports of the ith commodity to (a) the jth market and (b) the world market. This is the so-called 'market diversification effect', reflecting the effect of the growth in import demand for the ith commodity of the trading partners as compared with 
the growth in the demand for the same commodity in the world. The last component of identity (i) is the 'export promotion effect', which shows the difference between the actual expansion of a country's export trade and that which would have been obtained if the country had only maintained a constant share in the total world exports in every commodity.

\section{The Export Promotion Effect}

The 'export promotion effect' reflects the influence of various factors on exports, such as relative prices, changes in exchange rate, quality improvements, development of new exports, incentives to exporters, changes in the ability for prompt fulfilment of export orders, etc. ${ }^{2}$ It should be noted that while some factors affecting the export-promotion component are not quantifiable, on others the data are not available. ${ }^{3}$ Furthermore, since changes in the supply situation also affect a country's exports, we have used domestic production of exportables in addition to real effective exchange rate to explain the 'export promotion effect' which is given by equation (ii):

$$
\mathrm{EP}_{\mathrm{i}}=\alpha_{0}+\alpha_{1} \mathrm{REE}_{\mathrm{xi}}+\alpha_{2} \mathrm{Q}_{\mathrm{xi}}+\alpha_{3} \mathrm{D}_{1}+\alpha_{4} \mathrm{D}_{2}+\alpha_{5} \mathrm{D}_{3} \ldots
$$

where

$\mathrm{EP}_{\mathrm{i}}=$ Export promotion effect of the ith commodity in real term;

$\mathrm{REE}_{\mathrm{xi}}=$ Real effective exchange rate of the ith commodity;

$\mathrm{Q}_{\mathrm{xi}} \quad=$ Produced quantity of the ith commodity;

$\mathrm{D}_{1} \quad=$ Dummy variable, used to capture the effect of structural change in Pakistan's international trade due to breakaway of East Pakistan in 1971;

$\mathrm{D}_{2} \quad=$ Dummy variable assimilating the effect of stockpiles in 1971-1972 on exports during 1972-73 to 1974-75; and

$\mathrm{D}_{3} \quad=$ Dummy variable, used to capture the effect of establishment of rice and cotton trading corporations in 1973-1974.

The real effective exchange rates incorporate changes in the export-weighted exchange rates, relative price changes and changes in incentives.

${ }^{2}$ It may be noted that we can also study the impact of incentives, changes in exchange rate and relative prices in terms of changes in the real effective exchange rates.

${ }^{3}$ Other factors affecting the competitiveness in the world market are quality improvements, development of new exports and fulfilment of export orders.
The export-weighted index $\left(\mathrm{E}_{\mathrm{xi}}\right)$ may be estimated as follows:

$$
E_{x i}=\Sigma_{j} R_{j} \frac{X_{i j}}{\sum_{j} X_{i j}} \quad \cdots
$$

where

$\mathrm{X}_{\mathrm{ij}} / \sum_{\mathrm{j}} \mathrm{X}_{\mathrm{ij}}=$ Proportion of exports to the jth country, and

$R_{j} \quad=$ Exchange rate of Pakistani rupee with the jth importing country.

Adjusting equation (iii) for changes in relative prices, we get export-weighted index $\mathrm{E}_{\mathrm{xi}}^{\prime}$ in real terms as:

$$
E_{x i}^{\prime}=\frac{P_{w i}}{P_{c i}} \cdot E_{x i}
$$

where

$\mathrm{P}_{\mathrm{wi}}=$ Price of the ith exported good in the world market, and

$P_{c i}=$ Price of the ith exported good in the exporting country $E_{x i}^{\prime}$ does not take into consideration subsidies or export taxes.

In order to incorporate their effect equation (iv) may be written as

$$
\operatorname{REE}_{\mathrm{xi}}=\left(1+\mathrm{S}_{\mathrm{i}}-\mathrm{T}_{\mathrm{i}}\right) \mathrm{E}_{\mathrm{xi}}^{\prime} \quad \cdots
$$

where

$S_{i}=$ Subsidies to the ith exported good as a percentage of f.o.b. value;

$\mathrm{T}_{\mathrm{i}}=$ Export duties to the ith exported good as a percentage of f.o.b. value; and

$\mathrm{REE}_{\mathrm{xi}}=$ Real effective exchange rate for the ith commodity.

The analysis of export performance was limited to the 'world trade effect', 'commodity composition effect' and 'market diversification cum-export promotion effect', ${ }^{4}$ since the effect of market diversification on exports could not be analysed due to non-availability of exports data, broken down by destination, for a number of products. However, as the required data for rice, raw cotton, cotton yarn and thread, cotton fabrics, wearing apparel, carpets, other textiles, sports goods, and

${ }^{4}$ 'Market diversification-cum-export promotion effect' refers to the combined effects of market diversification and export promotion factors. 
leather and leather products were available, it was possible to decompose the growth of these exports. We had to limit a detailed analysis of the 'export promotion effect' to rice, raw cotton, cotton yarn and thread, and cotton fabrics, as price data relating to the rest of the commodities were not available for the world market due to lack of product identification.

To measure properly the export competitiveness of rice, raw cotton, cotton yarn and thread, and cotton fabrics, we require delivered prices by market, but they are not available. As a proxy for price, we have therefore, used unit export value of these commodities.

To analyse changes in the composition of trade, we have selected the 1972-1976 period. Any year earlier than 1972 would have affected the results as there occurred a structural change in Pakistan's international trade due to breakaway of East Pakistan, Pakistan's inter-regional trade was converted into its international trade. On the other hand, the analysis could not be extended beyond 1976 due to non-availability of cross country data. In the case of raw cotton, our analysis was restricted to 1975 because the production of cotton in 1976 was very poor.

To determine the factors giving rise to 'export promotion effect', one needs time series data for the 'export promotion' component and its regressors. Therefore, we went as for back as was allowed by the availability of the relevant data. We have selected the 1964-1976 period, ${ }^{5}$ for our study because the necessary data are not available for earlier years.

\section{EMPIRICAL RESULTS}

The results of the decomposition of Pakistan's export performance during the 1972-1976 period into its various components ${ }^{6}$ are given in Table 1. The second column shows the actual changes in exports over the 1972-1976 period. The third column shows the expected growth in Pakistan's exports in case they had increased at the growth rate of the world trade. The effect of the concentration of trade in specific products on exports is shown in the fourth column. In the fifth column, the combined 'market diversification-cum-export promotion effect' is shown. The sixth column shows the difference between the trend world growth rates of a specific product and total trade.

Table 1 shows that the decline in exports from 1972 to 1976 was mainly due to the concentration of Pakistan's trade in those products whose growth in the world

5 It may noted that since the CMS analysis is a comparative static and the analysis of 'export promotion effect' is essentially dynamic, as it requires time-series data to run the regression between 'export promotion effect' and its explanatory variables, the two studies, though interrelated, are not quite comparable.

${ }^{6}$ Since due to the non-availability of data, we could not incorporate 'market diversification effect' in our analysis, the 'market diversification-cum-export promotion effect' in Table 1 shows the impact of domestic policies as well as of the market diversification. demand was very sluggish as well as a number of factors which made the "market diversification cum-export promotion' effect negative were also somewhat responsible for it. It may be noted from column 2 that during the 1972-1976 period, exports of raw cotton, cotton yarn and thread, cotton fabrics, leather and leather products, toys, games and sports goods, fish and meat, non-metallic minerals hides and skins, wool and animal hairs, and crude animal materials declined significantly. Column 4 shows that the world demand for most of the commodities exported by Pakistan has grown at a relatively slower rate compared to the growth rate of world trade though in the cases of rice, raw cotton, petroleum products, oils and animal fats, plastic and rubber products, world demand did grow rapidly However, it may be noted that even in the case of these latter commodities the prospects of future growth in world demand are not very bright because these are either primary goods or traditional manufactured goods. The trends of world demand for most of Pakistan's export goods suggest that in the long run Pakistan should diversify her exports in such a way that those products for which the demand is growing rapidly constitute a large proportion of the total exports. The fact that the 'market diversification-cum-export promotion effect' is negative signifies that the country has lost its share in the world market. It follows that unless vigorous policies are pursued to boost her exports and divert them to rapidly growing markets it would be very difficult for Pakistan to increase or even maintain her percent share.

\section{Changes in Pakistan's Share of Exports of}

Selected Commodities in Market Areas

As necessary data were not available for fish and meat, tobacco and its products, non-metallic minerals, hides and skins, edible oils and animal fats, woo and animal hairs, crude animal materials, chemicals, plastic and rubber materials, paper and board, electrical machinery, non-electrical machinery, printing materials, and metal and metal products, we had to restrict the CMS analysis (including 'market diversification effect') to rice, raw cotton, cotton yarn and thread, cotton fabrics, other textiles, wearing apparel, leather and leather products, carpets and tapestries, and toys, games, and sports goods. The reuslts ${ }^{7}$ of this exercise are reported in Table 2.

It can be seen from column 2 of Table 2 that during the period from 1972 to 1976 the exports of rice, other textiles, wearing apparel, and carpets and tapestries increased significantly. The increase in the export of these products was mainly due to an increase in demand for these commodities in the importing countries. However, this is only a partial explanation as the 'export promotion effect' has been positive in all the cases, which shows that the various measures taken by the government to promote exports played a major role in improving the competitiveness of Pakistani exports in the world market. 
Changes in Exports During 1972-1976

\begin{tabular}{lcrrrr}
\hline \multicolumn{1}{c}{ Commodity } & $\begin{array}{c}\text { Actual change } \\
\text { in domestic } \\
\text { exports }\end{array}$ & $\begin{array}{c}\text { World } \\
\text { trade } \\
\text { effect }\end{array}$ & $\begin{array}{c}\text { Commodity } \\
\text { composition } \\
\text { effect }\end{array}$ & $\begin{array}{c}\text { Market diversi- } \\
\text { fication-cum- } \\
\text { export promotion } \\
\text { effect }\end{array}$ & $\mathrm{g}_{\mathrm{i}}^{*} \mathbf{g}^{*}$ \\
\hline Rice & $(2)$ & $(3)$ & $(4)$ & \multicolumn{1}{c}{$(5)$} & $(6)$ \\
Raw cotton (1972-1975) & 244.63 & 37.98 & 54.29 & 152.36 & 1.3 \\
Raw cotton (1972-1976) & 320.86 & 60.85 & 116.27 & 143.74 & 1.7 \\
Cotton yarn and thread & -566.60 & 136.37 & 19.13 & -722.10 & 1.7 \\
Cotton fabrics & -226.16 & 102.27 & -163.12 & -165.31 & -1.3 \\
Other textiles & -6.72 & 58.95 & -76.49 & 10.82 & -7.8 \\
Wearing apparel & 37.32 & 17.72 & -30.90 & 50.50 & -9.2 \\
Carpets and tapestries & 64.40 & 4.37 & -2.55 & 62.58 & -3.2 \\
Leather and leather products & 68.04 & 20.17 & -22.17 & 70.04 & -52.4 \\
Toys, games and sports goods & -62.20 & 43.39 & -60.50 & -45.09 & -16.1 \\
Fish and meat & -47.36 & 9.55 & -14.76 & -42.15 & -8.5 \\
Other foods & -20.60 & 17.76 & -32.50 & -5.85 & -11.1 \\
Tobacco and tobacco products & 3.21 & 4.51 & -1.36 & 0.07 & -1.3 \\
Non-metallic minerals & 2.71 & 4.60 & -6.24 & 4.35 & -5.8 \\
Hides and skins & -2.76 & 4.46 & -12.80 & 5.58 & -10.4 \\
Petroleum and petroleum products & -11.07 & 5.01 & -5.23 & -10.85 & -9.6 \\
\hline
\end{tabular}

Table $1-($ Contd. $)$

\begin{tabular}{|c|c|c|c|c|c|}
\hline Edible oils and animal fats & 15.49 & 0.30 & 0.59 & 14.91 & 2.7 \\
\hline Wool and animal hairs & -11.76 & 5.26 & -9.29 & -7.73 & -15.5 \\
\hline Crude animal materials & -4.54 & 2.95 & -5.12 & -2.37 & -10.5 \\
\hline Crude vegetable materials & 17.28 & 3.82 & -4.23 & 17.69 & -5.6 \\
\hline Chemicals & 1.94 & 2.30 & -2.10 & 1.74 & 0.1 \\
\hline Plastic and rubber products & 1.65 & 0.24 & 0.03 & 1.39 & -0.8 \\
\hline Paper and board & 0.53 & 0.70 & -0.58 & 0.41 & -4.5 \\
\hline Electrical machinery & 0.26 & 0.40 & -0.02 & -0.16 & -0.5 \\
\hline Non-electrical machinery & 0.18 & 0.86 & -0.42 & -0.26 & -1.3 \\
\hline Printing materials & 0.86 & 0.34 & -0.45 & 0.97 & -5.6 \\
\hline Metal and metal products & 0.68 & 0.58 & -0.29 & 0.39 & -1.5 \\
\hline Total Change: & $-481: 89$ & 490.07 & -345.97 & -626.20 & \\
\hline
\end{tabular}

Note: $\mathrm{g}^{*}$ and $\mathrm{g}^{*}$ are trend growth rates for the total world export and of export of the ith commodity respectively. It should be mentioned here that, to compute total change, the statistics used for raw cotton relate to $1972-1976$, not to $1972-1975$. 
The exports of raw cotton, cotton yarn and thread, leather and leather products, and toys, games and sports goods decreased largely due to the decline in world demand. However, there have been other factors responsible for a decline in these exports. ${ }^{8}$ In the case of raw cotton, the decline in export was due to domestic supply bottlenecks. Though in the case of cotton yarn and thread, leather and leather products, and toys, games and sports goods world demand has been growing very slowly, yet the growth in demand for the products in the countries importing from Pakistan has not been all that small. Pakistan has been unable to increase its share in world trade because it lost the competitive edge due to adverse government policies. ${ }^{9}$

Despite the fact that the world demand for cotton fabrics has declined, the exports of cotton fabrics from Pakistan remained almost stable during 1972-1976, mainly because the decline in world demand was counter-balanced by the improved competitive position in the world markets.

Since the CMS analysis takes into consideration only the base and the final years, the results can be sensitive to the choice of the period. To make sure that this is not the case, we conducted sensitivity analysis by changing the base year to 1973 . The result of this analysis, not reported here, shows that although the magnitude of change in the aforementioned four components is affected to some extent, the direction of the change is not affected at all. It follows that the choice of the year 1972 does not bias the results reported in Tables 1 and 2 .

\section{Analysis of the Export Promotion Effect}

Having accounted for the effect of the first three components in Table 2, we are left with the 'export promotion effect', which reflects the influences of the policies that an exporting country pursues to improve its competitiveness in the world market and the supply situation of exportables in the country. In this section are analysed the factors determining the 'export promotion effect' in Pakistan. The analysis is limited to rice, raw cotton, cotton yarn and thread, and cotton fabrics because the required data for other products are not available.

The 'export promotion effect' has been regressed on real effective exchange rate and domestic production of exportable. We used dummy variables to overcome the bias in our results due to structural changes, especially the one that occurred due to the separation of East Pakistan. The Ordinary Least Squares (OLS) method was used to estimate equation (ii), but where the serial correlation existed, the Generalized Least Squares (GLS) method was used. Raw cotton, cotton yarn and thread, and cotton fabrics were estimated by OLS method, while in case of rice we had to use the GLS.

${ }^{8}$ However, exports of raw cotton have increased over the 1972-1975 period.

${ }^{9}$ One of the reasons for low level of overall exports in Pakistan is the bias in government's policies against exports and in favour of import-competing products. Moreover, incentives have been granted to such exportable products as have declining world demand. 
It is clear from Table 3 that in the cases of rice, cotton yarn and thread, and cotton fabrics, competitiveness is explained largely by changes in the real effective exchange rates. These results suggest that decline in duties on rice exports made it more competitive in the world market, and was responsible for the rapid growth of rice exports witnessed in recent years. Effective Exchange Rates become ineffective when exports are made through some trading corporations. To capture this effect, a multiplicative dummy was introduced for rice and raw cotton. However, in both the cases it turned out to be insignificant. The duties on cotton yarn and thread have made them less competitive in the world market. Consequently, the exports of cotton yarn and thread have fallen. As mentioned earlier, despite the fact that the world demand for cotton fabrics has declined, the exports from Pakistan have remained almost the same during the $1972-1976$ period. This has been mainly due to the fact that the decline in world demand has been counter-balanced by the improved competitive position in the world market. The subsidy provided by the government to the exports of cotton fabrics was the main instrument which helped to maintain the share of cotton fabrics in the world market. It can be seen that the breakaway of East Pakistan did not have any significant impact on exports, which is largely a reflection of the fact that Pakistan was successful in diverting her exports to other markets. The domestic production of rice, cotton yarn and thread and cotton fabrics has turned out to be statistically insignificant. However, this fact in no way diminishes the importance of the effect of the increase in domestic production on exports. Given the level of domestic consumption, an increase in domestic production is a necessary condition for the growth of exports. It has been observed that there was excess capacity in the industries producing exportables and this excess capacity is expected to be utilized if there is an adequate increase in incentives. The effective exchange rate can also influence the level and rate of increase in output, adverse movements in the exchange rate act as a disincentive for increasing output. Due to this effect of exchange rates on production, unfavourable movements in these rates in the past may have over-shadowed the effect of production on exports, thus making the production-export relationship insignificant.

In the case of raw cotton, domestic production turns out to be the most significant variable in explaining the 'export promotion effect'; real effective exchange rate was found to be statistically insignificant as a factor explaining the growth of exports of raw cotton. This is not a surprising result as, following a poor cotton crop, the exports of raw cotton were curtailed by the government to keep alive the domestic textile industries. Since there were stock -piles of raw cotton in the early Seventies, mainly due to war with India in 1971, exports increased rapidly during the period from 1972-1973 to 1975-1976, even though output did not increase rapidly. 


\section{POLICY IMPLICATIONS}

Pakistan's balance of trade has always been in deficit, except in 1950-1951 and 1972-1973. In order to promote industrialization, capital goods and intermediate goods have to be imported because of the limited capacity of the domestic industries to produce these two types of goods. Furthermore, the import bill is heavily loaded with food-grains and with such items that a reduction in their inflow will hamper economic growth. However, exports have not grown rapidly enough to finance the increasing import bill.

Virtual stagnation in exports during the period from 1972 to 1976 is attributable to a number of factors, among which unfavourable commodity composition of Pakistan's export trade, concentration of export trade in sluggishly growing markets and government policies biased against exports, have been the main factors. Most of the products exported by Pakistan are either primary or traditional, for which the demand has not been growing fast enough in the world market. Even worse, the demand for these products has been growing even more sluggishly in those countries which have been importing from Pakistan. It follows that unless Pakistan shifts its reliance from traditional products to non-traditional products and from sluggishly growing markets to rapidly growing markets, there is not much scope for a substantial export expansion.

It is, therefore, necessary that the government should take measures both to enable the exporters to break into new markets and to bring about a switch over from traditional commodities to non-traditional commodities. The structure of incentives will have to be changed suitably because such a switch over involves transition costs in terms of intersectoral resource movement, the retraining of labourers for new skills, etc. As regards enabling the producers to be competitive in the world market, the government will have to provide subsidies to overcome any over-valution of the exchange rate [14]. Furthermore, the net protective margin on import substitution was about 22.1 percent in 1978-1979, which shows a bias against exports and leads to the flow of resources away from export-oriented industries ${ }^{10}$ [14]. Recently, the government has introduced a rebate scheme for traditional products, which again shows a bias against non-traditional products. This bias should be reversed.

As regards the measures which the government can take to capture new markets and strengthen the existing ones, strict quality control should be enforced to win over potential importers abroad. Similarly, efforts will have to be made to fulfil export orders promptly because non-fulfilment of orders in time amounts to an increase in the cost to foreign importers. The government can set up information agencies to gather data on export possibilities and then propagate it to the domestic

${ }^{10}$ For a more detailed discussion of the net protective margin with respect to export expansion efforts, see Naqvi [12]. producers. This would lead to an increase in informtion regarding the existence of international markets for the goods produced in Pakistan. Similarly, necessary information should be provided to importing countries to introduced Pakistani products. Moreover, foreign import regulations, market surveys, studies of consumption trends and elaboration of products, and certain other measures can help in exploring of new markets.

\section{CONCLUSIONS}

In this study we have analysed the main forces behind the decline in exports in real term over the 1972-1976 period when exports declined from Rs. 3068 million in 1972 to Rs. 2507 million in 1976, and have come to the conclusions that the decline in Pakistan's exports was attributable to three main factors, viz. unfavourable commodity composition, concentration of exports in sluggishly growing markets, and the bias against exports in government policies. In the cases of most of Pakistani exports, it is observed that the world demand for them is not increasing as fast as the total world demand for the rest of the products is growing; rice and raw cotton are the only two exceptions. However, even in the case of rice and raw cotton, the demand is growing sluggishly in the countries importing these products from Pakistan. Therefore, Pakistan will have to explore new markets which can absorb increased exports. On the other hand, exports of cotton yarn and thread, cotton fabrics, other textiles, carpets, leather and leather products, toys, games and sports goods, and wearing apparel, are going to markets where demand for these commodities is growing rapidly. This suggests that the world demand for most of the traditional and unprocessed goods is declining. Therefore, reliance on the exports of such goods is unfavourable for export expansion. The market diversification component suggests that we should extend our trade relations with the rapidly growing markets. Reliance on the traditional developed markets for exports has always led to a poor export performance. Developed markets have frequently adopted tariffs and quantitative restriction policies - with the result that terms of trade have been moving continuously against Pakistan.

The analysis of Pakistan's export performance through an intensive study of the 'export promotion effect' shows that changes in real effective exchange rates have been instrumental in the export promotion of rice, cotton yarn and thread, and cotton fabrics. Even though domestic production of rice, cotton yarn and thread, and cotton fabrics is statistically insignificant, this in no way denies the importance of the effect of the increase in domestic production on exports. In contrast to the above mentioned results for rice, cotton yarn and thread, and cotton fabrics, domestic production turns out to be a significant determinant of raw cotton export expansion. For whenever there was a poor cotton crop, the exports of cotton were curtailed by the government to feed the domestic textile industries. On the other hand, real effective exchange rate turns out to be statistically insignificant as a factor explaining the growth of raw cotton exports. 
The analysis presented in this study shows that the CMS technique provides useful information for analysing export performance by allowing realized export growth to be separated into commodity composition, market diversification, world trade and export promotion effects. The analysis of 'export promotion effect' provides information about the control variables which can be instrumental in formulating the future export policies. Quite apart from the 'export promotion effect', the study provides useful information concerning the extent to which the country is exporting to markets with relatively unfavourable growth rates. In addition to this, the analysis provides information regarding the nature of demand for the goods exported by Pakistan which may help significantly in the formulation of export policies.

\section{REFERENCES}

1. Balassa, B. "Recent Development in the Competitiveness of American Industry and Prospects for the Future". In U.S. Congress, Joint Economic Committee. Factors Affecting the United States Balance of Payments. Washington: U.S. Government Printing Office. 1962. pp. 27-54.

2. Fleming, J. M., and S.C. Tsiang. "Changes in Competitive Strength and Export Share of Major Industrial Countries”. International Monetary Fund, Staff Papers V. August 1958.

3. Food and Agriculture Organization. Trade Year Book. Rome (For the years 1973 to 1977 )

4. Food and Agriculture Organization. Monthly Bulletin of Agricultural Economics and Statistics. Rome. (For the years 1973 to 1977)

5. Houthakker, H. S., and S. P. Magee. "Income and Price Elasticities in World Trade”. Review of Economics and Statistics. Vol. LI, No. 2. May 1969.

6. Hussain, I. "Industrial Growth and Export Expansion: The Case of Pakistan”. Pakistan Development Review. Vol. XIII, No. 3. Autumn 1974.

7. International Monetary Fund. International Financial Statistics. Washington, D.C. (For the years 1973 to 1977)

8. International Cotton Advisory Committee. Cotton-World Statistics. Washington, D.C. (For the years 1973 to 1977).

9. Leamer, E.E., and R. M. Stern. Quantitative International Economics. Boston: Allyn and Bacon Inc. 1970.

10. Little, I., T. Scitovsky, and M. Scott. Industry and Trade in Some Developing Countries. London: Oxford University Press. 1970.

11. Mahmood, Zafar. "Changes in Export Shares and Competitive Strength". Islamabad: Pakistan Institute of Development Economics. 1980. Research Report Series No. 110.
12. Naqvi, Syed Nawab Haider. “On Optimizing 'Gains’ from Pakistan's Export Bonus Scheme”. Journal of Political Economy. Vol. 79. No. 1. JanuaryFebruary 1971.

13. Organization for Economic Co-operation and Development. Statistics of Foreign Trade, Trade by Commodities. Paris. (For the years 1973 to 1977)

14. Pakistan Institute of Development Economics. The State of Pakistan's Economy 1970-1971 to 1979-1980. Islamabad, 1980.

15. Radhu, G. M. "Trade Between East and West Pakistan at World Prices, 1960-1961 to 1969-1970". Pakistan Development Review. Vol. XII, No. 2. Summer 1973.

16. Richardson, J. D. "Constant Market Share Analysis of Export Growth". Journal of International Economics. Vol. 1, No. 2. May 1971.

17. State Bank of Pakistan. Bulletin. Karachi. (Issues for the years 1973 to 1978)

18. State Bank of Pakistan, Statistics Department. Export Receipts. (Issues for the years 1972 to 1977 )

19. Stern, R. M. Foreign Trade and Economic Growth in Italy. New York: Frederic A. Preager. 1967.

20. Tyszynski, H. "World Trade in Manufactured Commodities, 1899-1950". The Manchester School. Vol. XIX, September 1951.

21. United Nations. Year Book of International Trade Statistics. New York. (For the years 1973 to 1977) 